DOI: $10.2478 /$ ace-2013-0018

\title{
SYNERGISTIC INTERACTION OF POLYPROPYLENE FIBRES IN LATEX MODIFIED HIGH STRENGTH CONCRETE
}

\author{
S. THIRUMURUGAN, A. SIVAKUMAR ${ }^{1}$
}

\begin{abstract}
Synthetic polymer latexes, such as styrene-butadiene rubber (SBR) latex addition in Portland cement has gained wider acceptance in many applications in the construction industry. Polymer-modified cementitious systems seals the pores and micro cracks developed during hardening of the cement matrix, by dispersing a film of polymer phase throughout the concrete. A comprehensive set of experimental test were conducted for studying the compressive properties of SBR latex polymer with crimped polypropylene fibres at relative volume fractions of 0.1 and $0.3 \%$. The results indicated that the addition of polypropylene fibre has little effect on the reduction in the workability of concrete composite containing fly ash and SBR Latex. Increase in polypropylene fibres upto $0.3 \%$ $\mathrm{V}_{\mathrm{f}}$ showed increase in compressive strength upto 57.5MPa. The SBR concrete without fibre showed an increase in strength upto $20 \%$ compared to plain concrete. Test results also indicated that the compressive strength was increased in SBR fibre concrete by means of an ordinary dry curing process than wet curing because of their excellent water retention due to polymer film formation around the cement grains. On the contrary the compressive strength reduces for SBR fibre concretes under wet curing compared to dry curing.
\end{abstract}

Keywords: Compressive strength, Polymer concrete, Polypropylene fibres, Fly ash, Ultrasonic pulse velocity.

\section{INTRODUCTION}

The incorporation of synthetic polymers in Portland cement mortars and concrete started in the 1950's and polymer-modified cement mortars have led to the reduction in the permeability of the cement matrix which significantly improved the strength and durability of cement mortars. The applications of polymer-modified concrete has been used in various applications such as deck coverings for ships, bridges, paving, floorings, anti-corrosives, and adhesives. PMC is called as hydraulic cement combined with organic polymers that are dispersed in water, with or without aggregates. Since then, a greater interest on the use of synthetic polymer latex weighed over the use of the natural rubber latex in polymer-modified cement systems. Polymer latex addition to concrete shows increased bond strength, freezing-and thawing resistance, impact

1 Professor, Structural Engineering Division, VIT University, Vellore, Tamil Nadu, India. Email of corresponding author : sivakumara@vit.ac.in 
resistance, flexural strength, and reduced permeability. Polymer modified concrete also have increased resistance to water penetration and dissolved salts, and reduced need for sustained moist curing. The improvement of the properties of modified cementitious mixture varies with the type of polymer modifier used, whereas the proportioning of ingredients and mixing procedures are similar to conventional concrete. Sakai E, et. al., [1] studied that Polymer cement concrete has high tensile strength, good ductile behavior, and high impact resistance capability due to the formation of a three-dimensional polymer network through the hardened cementitious matrices. Chandra S, et. A1., [2] suggested that SBR latex increases the void-filling effect and bridging across the cracks, it also decreases the porosity and pore radius of the concrete. Furthermore, the transition zone in the concrete may be improved due to the adhesion of a polymer. Gengying Li, et. al., [3] investigated in his study that the addition of SBR latex to concrete increases the flexural strength significantly when containing 3-10 weight $\%$ of SBR and optimal use of SBR is 5\%. However, the compressive strength may increase with the addition of SBR latex, when adding $10 \%$ weight of SBR latex a reduced level of $16 \%$ is observed in compression strength. The specimens were remoulded after 2 days, and then cured for 5 days in water with a temperature of 20 C, and for another 21 days in room conditions. Machine Hsie, et. al., [4] investigated that the polypropylene fibres have good ductility, fineness, and dispersion so they can restrain the plastic cracks. Jianzhuang Xiao, et. al., [5] studied that polypropylene fibres can be utilized to control fresh and hardened properties of cement-based materials at ambient temperature, it has been found that PP fibres can decrease the plastic shrinkage and they also have a minor effect on the compressive and flexural strengths. Peng Zhang, et al [6] investigated that the addition of polypropylene fibre has little adverse effect on the workability of concrete composite containing fly ash and silica fume. However, the addition of polypropylene fibre has greatly improved the durability of the concrete composite containing fly ash and silica fume. However, the real effects of fibre addition showed reduction in water permeability, drying shrinkage strain and the carbonation depth. Generally hydration of cement occurs first as the cement particles hydrate and hardens, the polymer particles occupies the void spaces. The latex particles are typically greater than $100 \mathrm{~nm}$ in diameter; they cannot penetrate the small capillaries in the cement paste that may be as small as $1 \mathrm{~nm}$. Polymers fill in the larger capillaries and voids that can be most effective in reducing the pores in concrete. Zhengxian Yang, et. al., [7], investigations showed that usually a small amount of carboxylic acid is chemically bound onto the polymer particle surface which ionize in the highly alkaline environment of fresh mortar, tend to interact with calcium ions from the cement hydrates, which generally results in improved stability of the polymer latex and adhesion of the polymer-modified mortar to existing substrate. F.A. Shaker et.al., [8] suggested that polymer modified concrete has a pore size which is much smaller than that of the conventional concrete. The crystal deposition nor micro cracks were not found in the pores, whereas most of the pores were filled with the polymer latex. These characteristics highly reduce the possibility of fluid penetration 
through the PMC and greatly increase its durability performance. The transition zone of the PMC showed a lack of the well formed crystals of calcium hydroxide $(\mathrm{CaOH})$ in the surrounding area of the aggregate indicating a less porous zone, and thus overcoming the weakest link in the conventional concrete. Also reduction of the fracture crack width in the aggregate-paste interfacial region indicates a well developed bond between the aggregate and the polymer-cement co-matrix. The polymer film seems to form a connecting phase between the aggregate and the cement matrix. Extensive studies have been carried out in polymer modified concrete which showed that reduction in voids and limited studies have been carried out to study the bonding between the fibres and concrete. Due to its inherent adhesive property, SBR latex increases the compression, flexural strength, toughness and durability of concrete. The polypropylene fibers act as a bridge between cracks and also improve the flexural strength of concrete.

\subsection{RESEARCH SIGNIFICANCE}

The present study shows the important findings on compressive strength gain and the type of curing regime to be adopted for polymer modified concretes. Also the improvements on the concrete properties with the addition of polymeric fibers on the compressive strength were investigated. The present study also focuses on the interaction of SBR latex modified polypropylene fibre concrete replaced with $25 \%$ and $50 \%$ of flyash. A quantitative analysis of the compressive strength and ultrasonic pulse velocity for various polymer concrete mixture proportions were investigated.

\section{EXPERIMENTAL INVESTIGATION}

The details of materials used in the present experimental investigation are as follows.

\subsection{Cement}

Ordinary Portland cement of 53 grade having 28 days compressive strength of 47.9 MPa, satisfying the requirements of IS: $12269-1987$ was used in the present study. The specific gravity of cement was found to be 3.12.

\subsection{Fine AGgREGates}

River sand obtained from locally available source passing through $4.75 \mathrm{~mm}$ IS sieve, conforming to grading zone-II of IS: 383-1978 was used with fineness modulus of 2.49 and specific gravity of 2.67 . 


\subsection{Coarse aggregate}

Machine crushed well graded angular blue granite stone with $12.5 \mathrm{~mm}$ maximum size, conforming to IS: 383-1978 was used. The specific gravity and fineness modulus was found to be 2.73 and 6.9 respectively.

\subsection{Polypropylene fibre}

Crimped polypropylene fibres imported from Korea supplied by Onward Chemicals Pvt. Ltd, were used in the present study. The PP fibres used in the investigation was a low elastic modulus fibre which has a hydrophobic surface; and the balling effect of fibres was prevented by dry mixing in concrete. The property of the polypropylene fibres is shown in Table 1 and the snap shot of the fibre is given in Fig. 1.

Table 1

Physical properties of Polypropylene fibres

\begin{tabular}{|c|c|c|c|c|}
\hline $\begin{array}{c}\text { Length } \\
\mathrm{mm}\end{array}$ & $\begin{array}{c}\text { Diameter } \\
\mathrm{mm}\end{array}$ & $\begin{array}{c}\text { Tensile strength } \\
\mathrm{MPa}\end{array}$ & Aspect ratio & $\begin{array}{c}\text { Density } \\
\mathrm{Kg} / \mathrm{m}^{3}\end{array}$ \\
\hline 48 & 0.60 & 450 & 80 & 910 \\
\hline
\end{tabular}

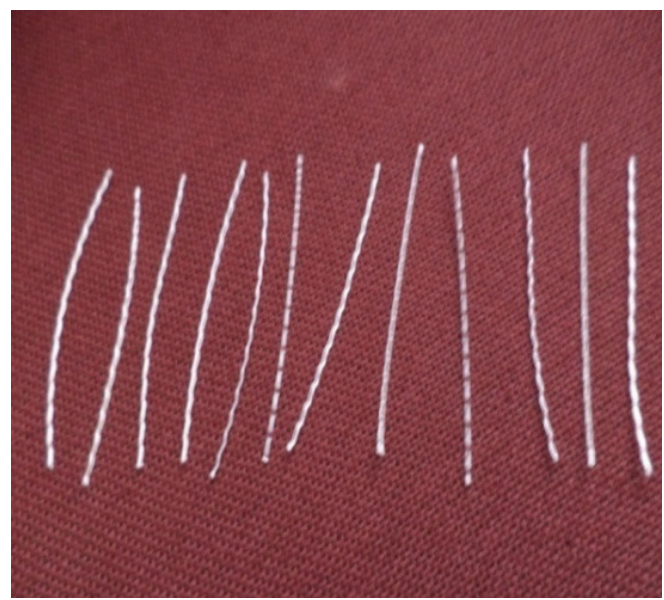

Fig. 1. Snap shot of Polypropylene fibres used

\subsection{STYrene Butadiene RUBber LATEX}

Styrene-butadiene rubber latex is a synthetic rubber having milky white appearance with low viscosity. The property of SBR latex is shown in Table 2 and the snap shot of the SBR latex is given in Fig. 2. 
Table 2

Physical and chemical properties of SBR latex

\begin{tabular}{|c|c|}
\hline Appearance & Milky white liquid \\
\hline PH value at $30^{\circ} \mathrm{C}$ & 8.1 \\
\hline Solid $\%$ & $45 \pm 2 \%$ \\
\hline Specific Gravity : & 1.01 \\
\hline Toxic & Non toxic \\
\hline
\end{tabular}

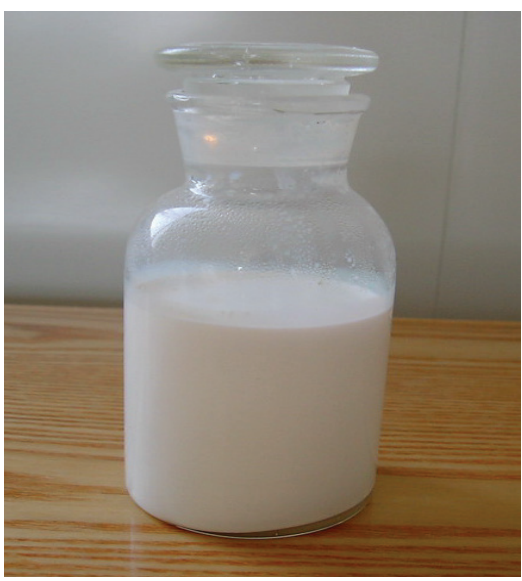

Fig. 2. Snap shot of SBR Latex used

\subsection{Chemical admixture}

A polycarboxylate ether based super-plasticizer condensate was used with specific gravity of 1.16 .

\subsection{FLYASH}

The class $\mathrm{F}$ flyash used in the study was pozzolanic in nature, and contains less than $10 \%$ lime $(\mathrm{CaO})$. The glassy silica and alumina of Class $\mathrm{F}$ fly ash requires a cementing agent, such as Portland cement, quicklime, or hydrated lime, with the presence of water in order to react and produce cementitious compounds. The properties of class F flyash are given in Table 3. 
Table 3

Chemical composition of Flyash

\begin{tabular}{|c|c|}
\hline Characteristics & Percentage (\%) \\
\hline Silica & 42.50 \\
\hline Iron Oxide & 8.3 \\
\hline Aluminum Oxide & 38.3 \\
\hline Calcium Oxide & 2.24 \\
\hline Magnesium Oxide & 0.6 \\
\hline Titanium Oxide & $<1$ \\
\hline Phosphorous & $<1$ \\
\hline Sulphates & 0.1 \\
\hline Alkali Oxide & $<1$ \\
\hline
\end{tabular}

The above details are taken from ETP

\subsection{Conceptual MiX Design}

In this study, the concrete mixtures adopted for the study were designed by conceptual mix design procedure and a total of 8 different concrete mixture proportions was prepared which consisted of two reference mix (with and without SBR latex and PP fibres). The mix proportions were arrived based on fine aggregate to coarse aggregate ratio of 0.6 , different volume fraction of polypropylene fibres and water to binder ratio of 0.3 was kept constant for all the studies. The proportions of all mixes were presented in Table 4.

Table 4

Mix Proportions of concrete

\begin{tabular}{|c|c|c|c|c|c|c|c|c|c|c|}
\hline \multirow[t]{2}{*}{$\begin{array}{l}\text { Mix } \\
\text { Id }\end{array}$} & \multirow[t]{2}{*}{$\begin{array}{l}\mathrm{w} / \mathrm{b} \\
\text { ratio }\end{array}$} & \multirow[t]{2}{*}{$\begin{array}{l}\mathrm{F} / \mathrm{C} \\
\text { ratio }\end{array}$} & Cement & Flyash & $\begin{array}{c}\text { Fine } \\
\text { aggregate } \\
\text { content }\end{array}$ & $\begin{array}{c}\text { Coarse } \\
\text { aggregate }\end{array}$ & Water & \multirow[t]{2}{*}{$\begin{array}{l}\begin{array}{c}\text { Polypro- } \\
\text { pylene }\end{array} \\
\text { Fibres } \\
(\%) \mathrm{Vf}\end{array}$} & \multirow[t]{2}{*}{$\begin{array}{l}\text { SBR } \\
\text { Latex } \\
\%\end{array}$} & \multirow[t]{2}{*}{$\begin{array}{c}\text { Super } \\
\text { plas- } \\
\text { ticizer } \\
(\%)\end{array}$} \\
\hline & & & \multicolumn{5}{|c|}{$\left(\mathrm{Kg} / \mathrm{m}^{3}\right)$} & & & \\
\hline M & 0.3 & 0.6 & 400 & 100 & 713 & 1188 & 120 & 0 & 0 & 1.5 \\
\hline M1 & 0.3 & 0.6 & 400 & 200 & 675 & 1125 & 120 & 0 & 0 & 1.5 \\
\hline $\mathrm{S}$ & 0.3 & 0.6 & 400 & 100 & 713 & 1188 & 120 & 0 & 7 & 1.5 \\
\hline S1 & 0.3 & 0.6 & 400 & 200 & 675 & 1125 & 120 & 0 & 7 & 1.5 \\
\hline
\end{tabular}


Table 4

\begin{tabular}{|l|l|l|l|l|l|l|l|l|l|l|}
\hline MSF1 & 0.3 & 0.6 & 400 & 100 & 713 & 1188 & 120 & 0.1 & 7 & 1.5 \\
\hline MSF2 & 0.3 & 0.6 & 400 & 200 & 675 & 1125 & 120 & 0.1 & 7 & 1.5 \\
\hline MSF3 & 0.3 & 0.6 & 400 & 100 & 713 & 1188 & 120 & 0.3 & 7 & 1.5 \\
\hline MSF4 & 0.3 & 0.6 & 400 & 200 & 675 & 1125 & 120 & 0.3 & 7 & 1.5 \\
\hline
\end{tabular}

\subsection{CASTING OF SPECIMEN}

The cement, aggregates and flyash were mixed first in a pan type concrete mixer of capacity $40 \mathrm{Kg}$ for a period of 3 minutes, and then a superplasticizer dosage of $1.0 \%$ was added to the concrete mix to achieve the desired consistency. Polypropylene fibres and SBR latex (7\%) were then added into the pan mixer and the mixing was continued for 2 minutes and were transferred into the casted in steel cube moulds of standard size $100 \times 100 \times 100 \mathrm{~mm}$ and were compacted on a table vibrator. The surface finishing was done very carefully to obtain a uniform smooth surface.

\subsection{Curing CONDITION}

In this research study, different types of curing regime were adopted for all specimens. SBR latex fibre concrete after remoulding was cured under wet, dry and hot water condition. The specimen were wet and dry cured separately for each mix proportions for 28 days, whereas for hot water curing, the specimen were kept in hot water bath for 2 hour after remoulding and then water cured for 28 days. In this study another curing regime followed for the latex fiber specimen is water curing for 6 days and then kept air dried for 22 days at room temperature, whereas reference concrete is normal water cured. The Tests were performed at 1day, 3 day, 7 day and 28 day for all curing condition.

\subsection{INITIAL AND FINAL SETTING TIME}

The time interval between addition of water and beginning of solidification (loss of consistency) is known as initial setting time. The water-cement ratio of 0.3 is constant for all the mix proportions. The depth of penetration of the needle for initial setting time is when paste stiffens sufficiently for needle to a point $5 \pm 1 \mathrm{~mm}$ from the bottom, initial set is said to have taken place. Final setting time is the time taken for the initiation of hardening process.

\subsection{Compressive STRENGTH}

The compressive strength of cubes $100 * 100 * 100 \mathrm{~mm}$ was performed on the compression testing machine of $2000 \mathrm{kN}$ loading capacity. The specimen of all mixes was tested at 1 day, 3day, 7day and 28day. The details of the setup are shown in Fig. 3. 


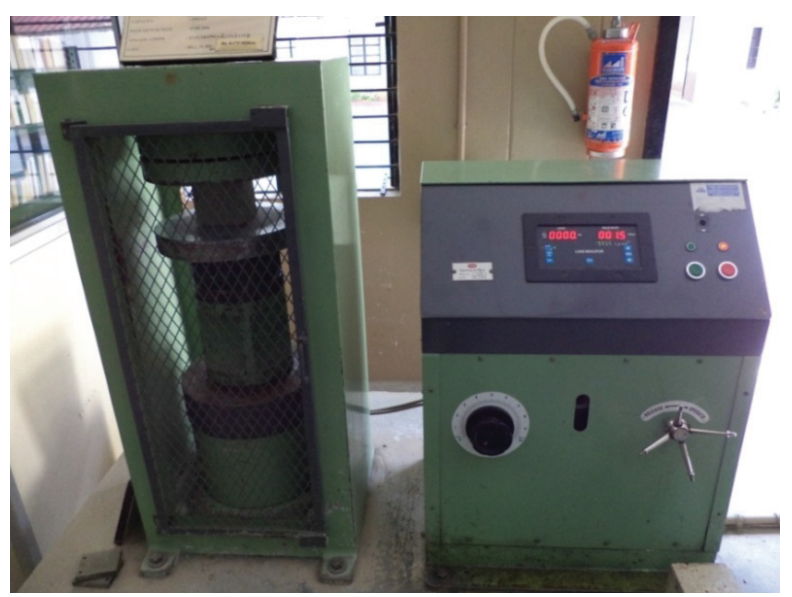

Fig. 3. Test set up for Compression testing machine

\subsection{Ultrasonic PULSE VELOCITY}

Quality of concrete was monitored using ultrasonic pulse velocity tester, which involves measurement of the time of travel of an ultrasonic pulse passing through the concrete; the pulse generator consists of electronic circuit for generating pulses and a transducer for transforming these electronic pulses into mechanical energy having pulse frequency of $50 \mathrm{KHz}$. The path length between transducer divided by the time of travel gives the average velocity of wave propagation to be tested for various mixture proportions of concrete. The details of the setup are shown in Fig. 4.

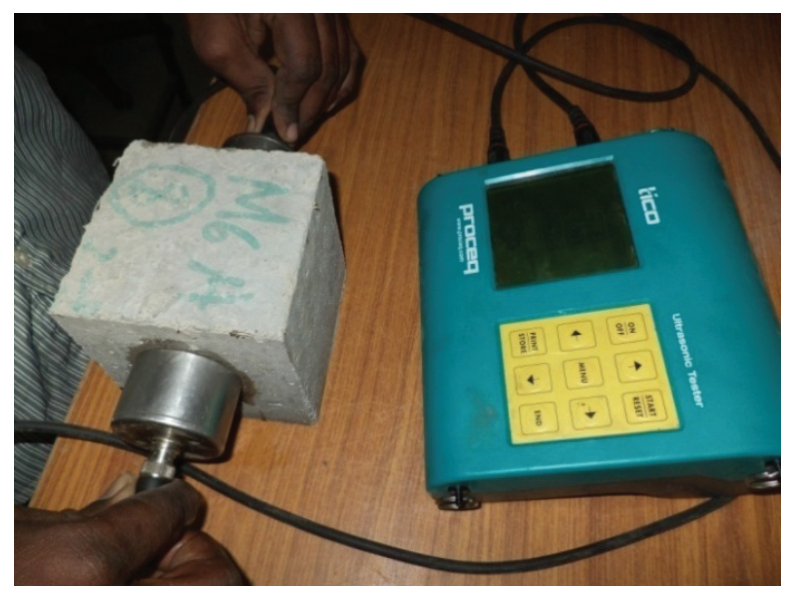

Fig. 4. Test set up for Ultrasonic Pulse Velocity 


\section{EXPERIMENTAL TEST RESULTS AND DISCUSSION}

Test results are presented graphically and in tabular forms and have been discussed under various categories.

\subsection{INITIAL AND FINAL SETTING TIME}

The consistency of cement obtained was $32 \%$ for OPC 53 grade cement. The increase in the fly ash percentage with cement shows decrease in the initial setting time $165 \mathrm{~min}$ compared to cement, fly ash with SBR latex $185 \mathrm{~min}$. It was observed that addition of latex to cement and fly ash shows increase in workability and initial setting time. The final setting time of cement, flyash with SBR latex records early setting of $340 \mathrm{~min}$ compared to cement $422 \mathrm{~min}$ and composition of cement and flyash , $445 \mathrm{~min}$. Addition of latex not only increase the workability it provide time for initial setting of cement and early hardening of cement matrix. The details of initial and final setting time are shown in Table 5.

Table 5

Initial and Final Setting Time

\begin{tabular}{|c|c|c|}
\hline Material & Initial setting time (min) & Final setting time (min) \\
\hline Cement & 125 & 422 \\
\hline Cement + flyash 25\% & 165 & 445 \\
\hline Cement + flyash 50\% & 190 & 523 \\
\hline Cement + flyash 25\% + SBR 7\% & 185 & 340 \\
\hline Cement + flyash 50\% + SBR 7\% & 194 & 380 \\
\hline
\end{tabular}

\subsection{PRoperties OF FRESH CONCRETE}

Fresh concrete containing SBR latex with polypropylene fibre is workable for very low water cement ratio but increase in fibre volume fraction workability is reduced. Addition of SBR latex to concrete provides good adhesion between the concrete and fibres, whereas Increase in the flyash content from $25 \%$ to $50 \%$ reduces the workability of concrete due to fineness of flyash. The concrete with SBR latex provides good workability and reduce the need of water content which also initiates early setting of concrete after mixing. The additions of high range water reducers reinstates the consistency of polymer modified concrete with polypropylene fibre mixes. 


\subsection{Compressive Strength of CONCRETE}

The various test results for compressive strength of concrete with and without SBR latex and fibres are summarized in Table 6 and represented in Figures 5, 6 and 7. The maximum strength of concrete is obtained for higher substitution of polypropylene fibres at $0.3 \%$, which exhibited a highest compressive strength of $57.5 \mathrm{MPa}$ at 28 days compared to plain concrete of 44MPa. However, it can be observed from the test results that the steady increase in strength was achieved for higher replacement levels of polypropylene fibres with SBR latex when the specimen is cured 6 days under wet curing followed by air curing at room temperature for 22 days. In general all the SBR fibre concrete mixtures exhibited positive increase in strength for specific curing regime in which specimens are cured for 6days in water and then completely air cured. This significantly shows that for the initial curing period complete hydration period are effected and after the required surface hydration and air drying of the samples provided further polymerisation.

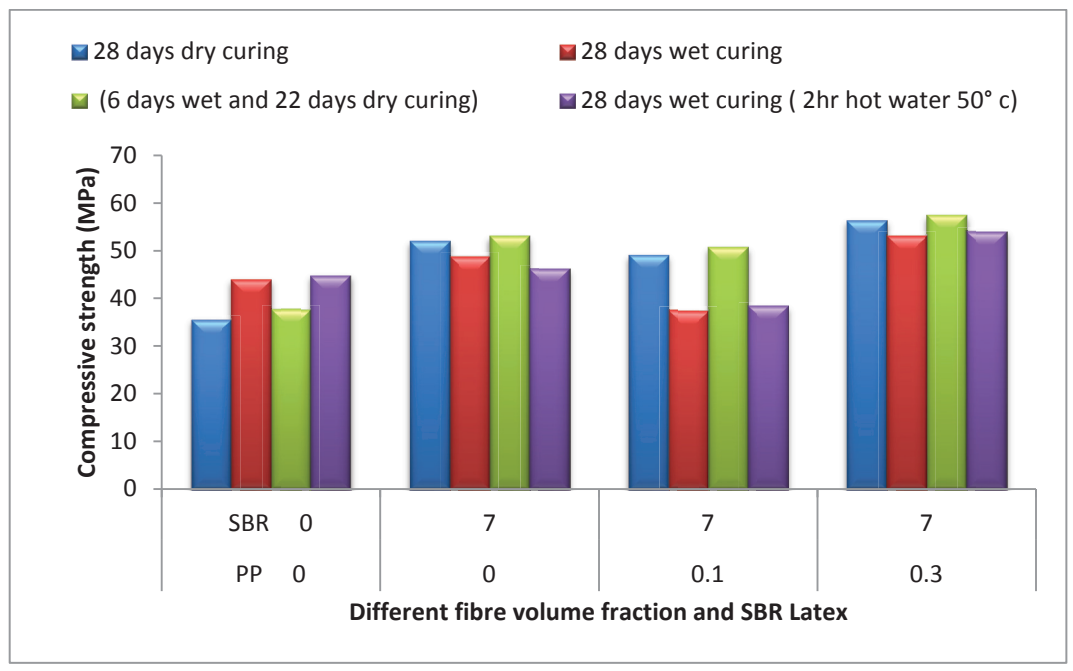

Fig. 5. Compressive strength at different percentage of fibre and SBR latex 


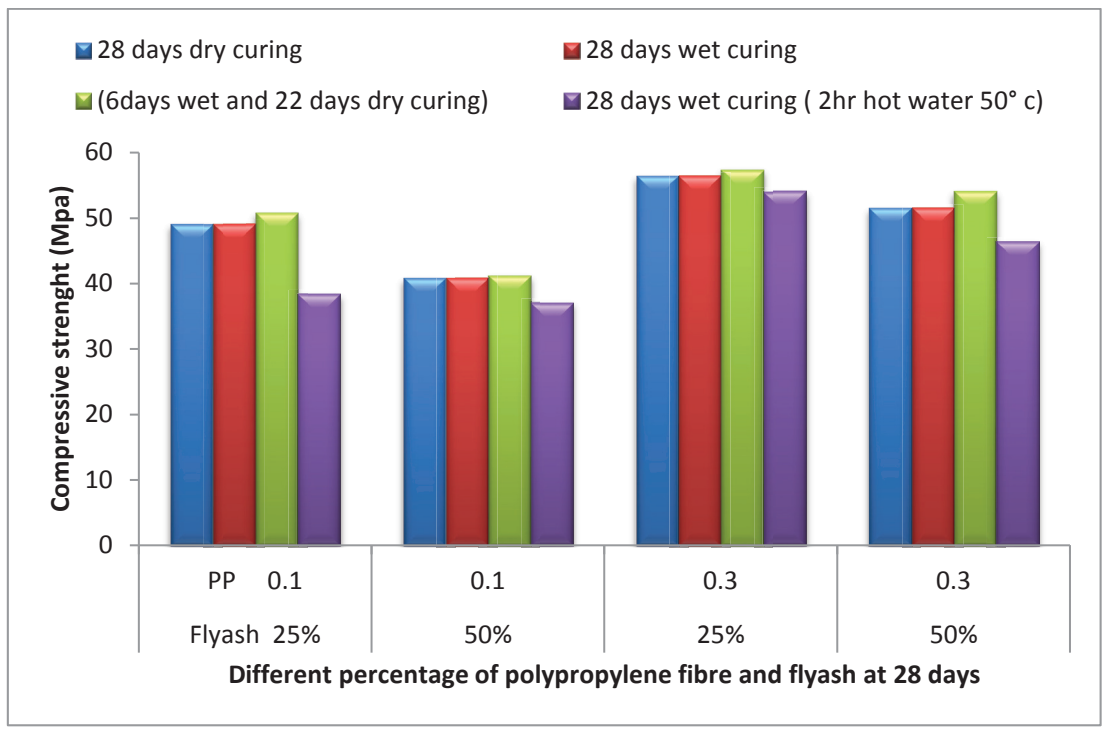

Fig. 6. Compressive strength at different percentage of fibre and flyash

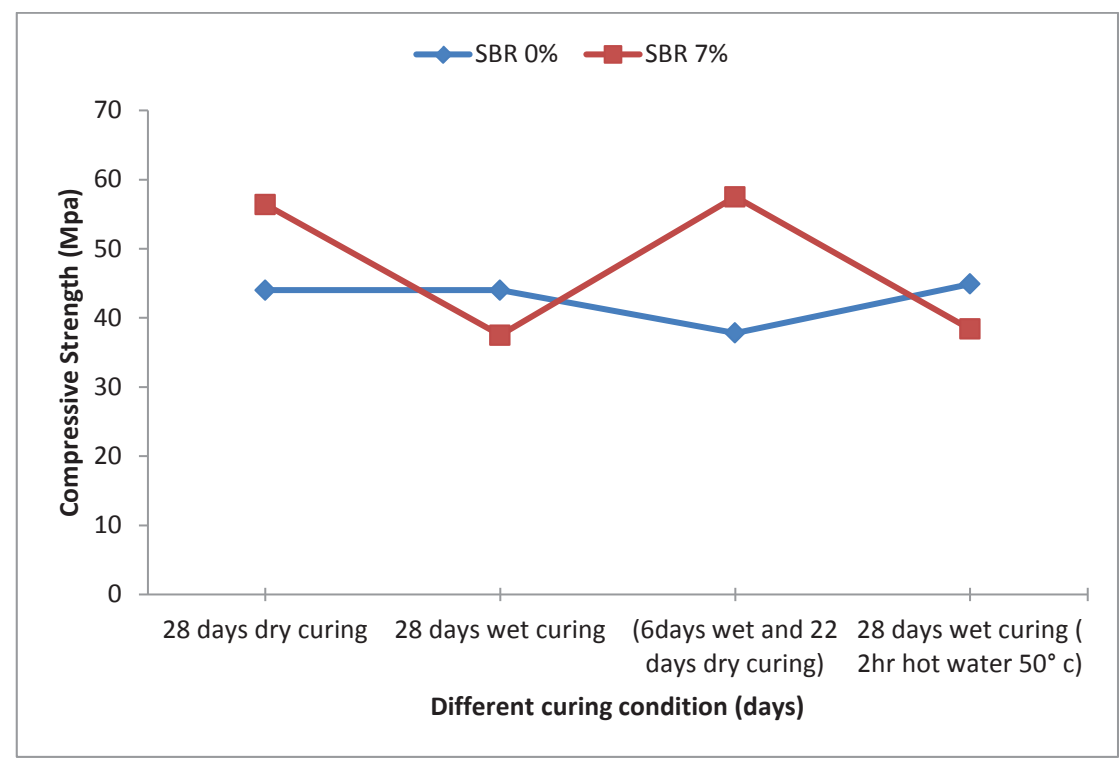

Fig. 7. Compressive strength of plain and polymer modified concrete at 28 days 
Table 6

Compressive strength of concrete for different mixture proportions

\begin{tabular}{|c|c|c|c|c|c|c|c|c|c|}
\hline \multirow[b]{2}{*}{ Mix Id } & \multicolumn{9}{|c|}{ Compressive strength for various curing days $(\mathrm{MPa})$} \\
\hline & 1 day & $\begin{array}{c}3 \text { days } \\
\text { dry } \\
\text { curing }\end{array}$ & $\begin{array}{l}3 \text { days } \\
\text { wet } \\
\text { curing }\end{array}$ & $\begin{array}{l}7 \text { days } \\
\text { dry } \\
\text { curing }\end{array}$ & $\begin{array}{c}7 \text { days } \\
\text { wet } \\
\text { curing }\end{array}$ & $\begin{array}{c}28 \text { days } \\
\text { dry } \\
\text { curing }\end{array}$ & $\begin{array}{c}28 \text { days } \\
\text { wet } \\
\text { curing }\end{array}$ & $\begin{array}{c}\text { (6days } \\
\text { wet and } \\
22 \text { days } \\
\text { dry } \\
\text { curing) }\end{array}$ & $\begin{array}{c}28 \text { days } \\
\text { wet } \\
\text { curing } \\
(2 \mathrm{hr} \text { hot } \\
\text { water } \\
\left.50^{\circ} \mathrm{c}\right) \\
\end{array}$ \\
\hline M & 23.4 & 26.2 & 30.5 & 31.4 & 34.8 & 35.6 & 44 & 37.8 & 44.9 \\
\hline M1 & 17.4 & 23.1 & 25.6 & 30.3 & 34.8 & 34.6 & 39.5 & 37.4 & 41 \\
\hline $\mathrm{S}$ & 28.1 & 34.9 & 31.6 & 41.3 & 37.2 & 52.1 & 48.9 & 53.2 & 46.2 \\
\hline S1 & 21.1 & 27.1 & 25.1 & 32.9 & 29.8 & 49.7 & 42.5 & 52.1 & 43.1 \\
\hline MSF1 & 27.1 & 34.8 & 31.6 & 40.1 & 35.6 & 49.1 & 37.5 & 50.8 & 38.4 \\
\hline MSF2 & 20.1 & 23.5 & 22.3 & 30.9 & 28.6 & 40.8 & 35.4 & 41.2 & 37.1 \\
\hline MSF3 & 30.1 & 35.6 & 33.1 & 38 & 36 & 56.4 & 53.2 & 57.5 & 54.1 \\
\hline MSF4 & 29.3 & 35.9 & 31.2 & 35.1 & 32.9 & 50 & 45.6 & 54.1 & 46.4 \\
\hline
\end{tabular}

Note : Test results represent the average of 5 specimens for each sample

\subsection{Ultrasonic PULSE Velocity teST}

The ultrasonic pulse velocity test is a non destructive method based on the pulse techniques and predicts the quality of concrete for different mixture proportion. The polymer modified fibre concrete with respect to different curing ages is given in the Table 7. The experimental test results showed that higher enhancement of the strength for the ultrasonic pulse velocity as shown in Fig. 8. The ultrasonic pulse velocity values exposed an increasing trend for different concrete mixes with the pulse velocity values in the range of 2800 to $4600 \mathrm{~m} / \mathrm{s}$. However, UPV values were found to be higher (4610 $\mathrm{m} / \mathrm{sec}$ ) for concrete mixes containing $\mathrm{F} / \mathrm{C}$ ratio of 0.6 , and SBR latex with $0.3 \%$ polypropylene fibres. Also, the test results indicated that and all the values were found to be satisfied as per Indian standard. 
Table 7

Ultrasonic pulse velocity for various concrete specimens

\begin{tabular}{|c|c|c|c|c|c|c|c|c|c|}
\hline \multicolumn{10}{|c|}{ Ultrasonic pulse velocity (m/sec) } \\
\hline Mix Id & 1 day & $\begin{array}{l}3 \text { days } \\
\text { dry } \\
\text { curing }\end{array}$ & $\begin{array}{l}3 \text { days } \\
\text { wet } \\
\text { curing }\end{array}$ & $\begin{array}{l}7 \text { days } \\
\text { dry } \\
\text { curing }\end{array}$ & $\begin{array}{l}7 \text { days } \\
\text { wet } \\
\text { curing }\end{array}$ & $\begin{array}{l}28 \text { days } \\
\text { dry } \\
\text { curing }\end{array}$ & $\begin{array}{c}28 \text { days } \\
\text { wet } \\
\text { curing }\end{array}$ & $\begin{array}{c}\text { (6day } \\
\text { wet and } \\
22 \text { days } \\
\text { dry } \\
\text { curing) }\end{array}$ & $\begin{array}{c}28 \text { days } \\
\text { wet curing } \\
(2 \mathrm{hr} \text { hot } \\
\left.\text { water } 50^{\circ} \mathrm{c}\right)\end{array}$ \\
\hline M & 2890 & 3180 & 3250 & 3590 & 3890 & 3830 & 4320 & 3910 & 4310 \\
\hline M1 & 2910 & 3210 & 3290 & 3480 & 3820 & 3710 & 4180 & 3810 & 4210 \\
\hline $\mathrm{S}$ & 3330 & 3740 & 3610 & 4240 & 4420 & 4510 & 4420 & 4580 & 4410 \\
\hline $\mathrm{S} 1$ & 3140 & 3350 & 3450 & 4150 & 4210 & 4350 & 4250 & 4410 & 4340 \\
\hline MSF1 & 3270 & 3580 & 3650 & 3895 & 3920 & 4210 & 4420 & 4250 & 4430 \\
\hline MSF2 & 3150 & 3320 & 3490 & 3680 & 3990 & 4220 & 4310 & 4240 & 4390 \\
\hline MSF3 & 3310 & 3650 & 3820 & 3920 & 4010 & 4460 & 4390 & 4490 & 4390 \\
\hline MSF4 & 3560 & 3470 & 3710 & 3820 & 3910 & 4560 & 4210 & 4610 & 4310 \\
\hline
\end{tabular}

Note : Test results represent the average of 5 specimens for each sample

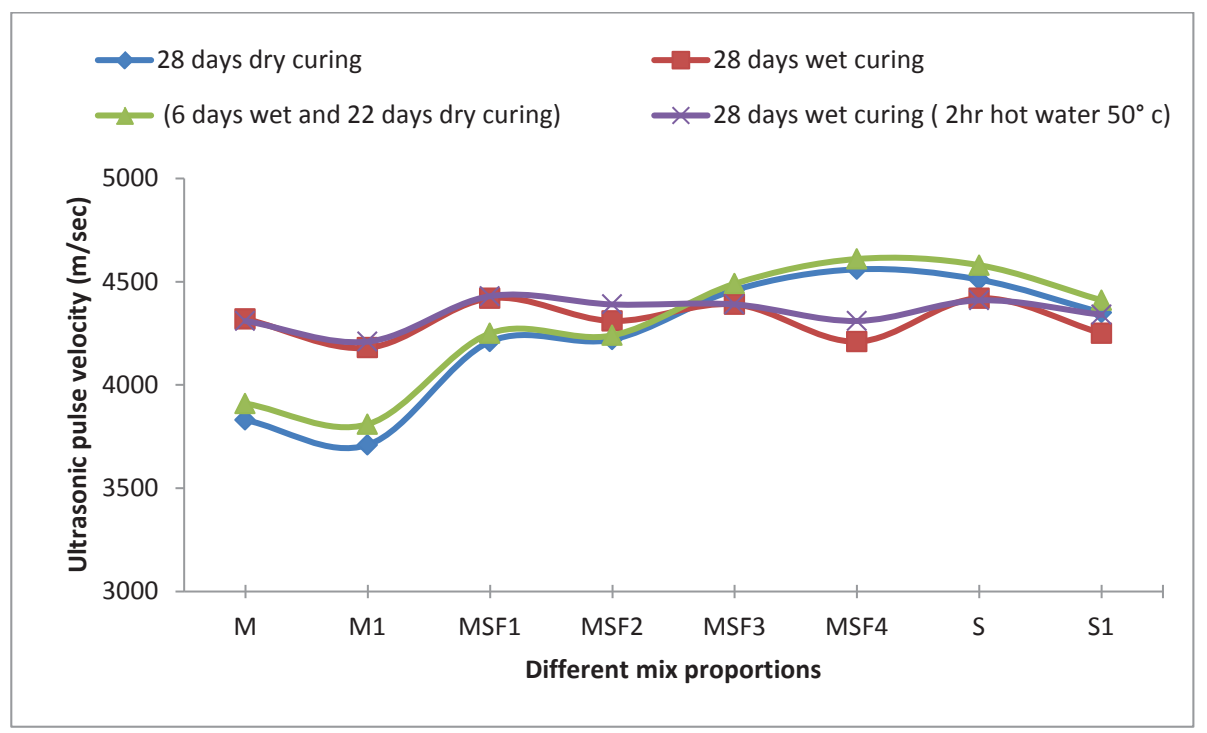

Fig. 8. Ultrasonic pulse velocity for different mix proportions 


\section{Conclusions}

Based on the experimental investigation the following conclusions are drawn within the limitations of the test results.

The workability of all the concrete mixes used in the study showed good improvement due to the addition of SBR latex even at low water cement ratio of 0.3 and this exhibited improved compressive strength properties in plain concrete and showed a highest compressive strength of 53.2MPa.

Further the addition of randomly distributed polypropylene fibres at $0.3 \%$ and SBR latex at $7 \%$ in plain concrete showed an appreciable strength enhancement in compression upto $57.5 \mathrm{MPa}$.

In the case of polymer modified concretes the rate of hardening was phenomenal in the case of dry curing compared to water curing; since, the water cured specimens does not develop faster hardening due to development of polymer film at the concrete surface which resist water penetration.

The addition of SBR latex to the plain concrete also exhibited early strength gain properties and showed a maximum one day compressive strength of $30.1 \mathrm{Mpa}$.

The compressive strength of SBR latex fibre concrete showed a reduction for wet curing compared to dry curing for all samples. However, wet curing for 6 days and air curing for 22 days showed significant increase in compressive strength than complete air dry curing method.

\section{REFERENCES}

1. E.Sakai, J.Sugita, Composite mechanism of polymer modified cement, Cement and Concrete Research, 25, 127-35, 1995 .

2. S. Chandra, P. Flodin, Interactions of polymer and organic admixtures on Portland cement hydration, Cement and Concrete Research, 17, 875-900, 1987.

3. Gengying Li, Xiaohua Zhao, Chuiqiang Rong, Zhan Wang, Properties of polymer modified steel fibrereinforced cement concretes, Construction and Building Materials, 24, 1201-1206, 2010.

4. Machine Hsie, Chijen Tu, P.S. Song, Mechanical properties of polypropylene hybrid fibre-reinforced concrete, Materials Science and Engineering, A 494, 153-157, 2008.

5. Jianzhuang Xiao, H. Falkner, On residual strength of high-performance concrete with and without polypropylene fibres at elevated temperatures, Fire Safety Journal, 41,115-121, 2006.

6. Peng Zhang, Qing-fu Li, Effect of polypropylene fibre on durability of concrete composite containing fly ash and silica fume, Composites, Part B 45,1587-1594, 2013.

7. Zhengxian Yang, Xianming Shi, Andrew T. Creighton, Marijean M. Peterson, Effect of styrenebutadiene rubber latex on the chloride permeability and microstructure of Portland cement mortar, Construction and Building Materials, 23, 2283-2290, 2009.

8. F.A Shaker, A.S El-Dieb, M.M Reda, Durability of Styrene-Butadiene Latex Modified Concrete, Cement and Concrete Research, 27, 711-720, 1997.

9. Alizadehnozari Mehdi, Neka, Structural Reinforcement of Building Materials using Polymer Concrete, 23, 135-143, 2011. 
10. G R Harish, S A K Zai, Behavior Of SBR-Latex Modified Polypropylene Fibre Reinforced Railway Sleepers Under Static Loading, 35th Conference on our world in concrete \& structures, 25-27, 2010.

11. Ke-Ru Wu, Dong Zhang, Jun-Mei Song, Properties of Polymer-modified Cement mortar using PreEnveloping Method, Cement and Concrete Research, 32,425-429, 2002.

12. Chunxiang Qian, Piet Stroeven, Fracture properties of concrete reinforced with steel-polypropylene hybrid fibres, Cement \& Concrete Composites, 22, 343-351, 2000.

13. N. G. McCrum, C. P.Buckley, C. B. Bucknali, Principles of Polymer Engineering, Oxford University Press, $2^{\text {nd }}$ Edition, 447, 199.7

14. N. Lakshmanan, P .Srinivasulu, Muthumani, B .SivaramaSarma, N. Goplakrishnan, Behavior of Fibre Reinforced Concrete Beams under Repeated Impact Loading, Proceedings of ASCE, Journal of Structural Engineering,18, 21-30, 1991.

15. C.Vipulanandan, E .Paul, Performance of epoxy and polyester polymer concrete, ACI Materials Journal, 241-251, 1991. 